Article

\title{
Segmentation, Classification, and Determinants of In-Store Shopping Activity and Travel Behaviour in the Digitalisation Era: The Context of a Developing Country
}

\author{
Tri Basuki Joewono ${ }^{1, *}$, Ari K. M. Tarigan ${ }^{2} \mathbb{D}$ and Muhamad Rizki ${ }^{1}$ \\ 1 Department of Civil Engineering, Faculty of Engineering, Parahyangan Catholic University, \\ Jl. Ciumbuleuit No. 94, Bandung 40141, Indonesia; muhamadrizki1404@gmail.com \\ 2 Department of Safety, Economics and Planning, Faculty of Science and Technology, University of Stavanger, \\ P.O. Box 8600 Forus, 4036 Stavanger, Norway; ari.tarigan@uis.no \\ * Correspondence: vftribas@unpar.ac.id
}

Received: 25 February 2019; Accepted: 11 March 2019; Published: 15 March 2019

check for updates

\begin{abstract}
The influence of digital technologies in the current era has substantially affected the way individuals engage with in-store shopping activities and travels. To prepare a transport policy with sustainable orientations, it is important to investigate factors that determine in-store activity-travel patterns. In particular, knowledge about how in-store activities and travels interact with other forms of activities and travels should be updated, since the use of Information and Communications Technology (ICT) may be substantial to create new patterns of activity and travel. It is believed that shopping travel and activity behaviours may indicate the increase or decrease of physical travels, which is crucial for carbon emission measures in transportation sector. While numerous studies about this issue have been recently carried out based on the context of developed countries, little is known for the context of developing countries. To offer a better understanding of the nature of in-store shopping travels and activities in the digitalisation era, a household survey was conducted in Bandung, Indonesia. This survey tends to acquire data from respondents as a representation of developing countries on their shopping behaviour, travel characteristics, and spatial attributes that represent the conditions of their built environment. The results from the survey show that individuals in a developing country are still having interest in in-store grocery shopping even though their daily life has a close connection with digital life. The results of the analysis show that grocery shoppers in a developing country simultaneously consider shopping activity, other activities, modes of transport, and shopping expenses. This manifests in the form of trip-chaining activities and affects decisions on the modes of transport used. The results indicate a significant portion of trip frequency for in-store shopping travel with motorised modes. Since motorised modes are the main contribution for carbon emission production in transportation sector, the results of this study are critical for developing transport demand measures and setting relevant policy schemes to improve the sustainability of transportation system, especially for the context of developing countries.
\end{abstract}

Keywords: ICT; in-store shopping activity; grocery shopping; travel behaviour; travel pattern; developing country

\section{Introduction}

Shopping activities and travel form a complex process that begins with collecting information about a product and includes the final decision to purchase it [1,2]. Its complexity also affects the process of decision-making to select a shopping location, based on a trade-off between several 
factors including socio-demographics, the built environment and accessibility [3,4]. With the existing constraints, individuals will try to find a way to optimise the use of resources (time, space, and cost). Shopper's decision about their regularity to visit shops, whether they are routine or random, as well as the possibility to switch shops is determined by their demographic and purchase behavioural characteristics, namely opportunity cost [5]. The arrangement manifests in the combination of the mode choice and its departure time choice, where shopping trips have wider time window than precise time for work-related trips [6], as well as mode and destinations [7]. Individuals will also manage the shopping activities by combining the trips with other destination (multi-stops) as well as combining purchases of different goods during a single shopping trip (multi-purpose) [8]. The strategy of multi-purpose shopping behaviour is also applied as a mechanism to minimise the total effort in the shopping cycle [9]. When there are opportunities for reducing travel costs by sharing with other trips for non-shopping purposes, individual will also try to optimise the frequency of shopping at a given location [10]. Studies about the decision-making of shopping activities also covered its regularity and frequency. Bhat et al. [11] developed a methodology to investigate the determinants of the regularity and frequency of shopping activity behaviour including the type of shoppers (erratic or regular). Complexity is believed to increase when the heterogeneity is considered, as stated by Sun et al. [12] that heterogeneity across individual manifests in the diversification of shopping behaviour, which may involve shopping trips, as well as the diversity in shopping locations and frequency. Based on these studies, it is obvious that there is a need to identify the segment of in-store shoppers and examine the hitherto unobserved interaction between mode choice and shopping activity allocation. In addition, an explanation of the determinants of the frequency of in-store shopping trips and time allocation may be essential in creating systematic policies to help overcome transportation-related issues.

Studies have argued that the adoption of information and communications technology (ICT) has also contributed to an increase in the complexity of shopping activities and travel behaviour (for example, see Mokhtarian [13], Hsiao [14], Mokhtarian and Salomon [15], Schmid and Axhausen [2]). Although the trend towards online-related shopping activities has grown rapidly, in-store shopping activities are still an essential part of daily travel and activities for individuals and households. As a fact, innovation in retailing and the growth in online shopping infrastructure has been changing the nature of shopping activity to response the change [16]. According to Santos et al. [17], about $20 \%$ of all household travel and 15\% of vehicle miles travelled in the US are associated with shopping activities. Lee et al. [18] have also shown that although online shopping has grown significantly over the past few years, traditional stores still dominated the retail market share in the US in 2014.

There is a growing interest from academicians and many professionals in understanding how shopping behaviour is changing and potential implications for the future [16]. Urban planners and researchers need to examine the nature of in-store shopping travel and activity patterns and their consequences in terms of sustainable transportation, especially in the current era of digitalisation, as in-store shopping activities and travel contribute to transportation-related challenges such as traffic congestion and dependency on vehicle transport. The rise of different forms of shopping (i.e., online and offline shopping) may lead to the next question about whether recent forms of shopping travel and activity have significantly contributed to the change of physical travel with motorised transport modes. Implications of transport demand should be studied [19,20], particularly in addressing the challenge of meeting climate change goals, which is likely to dominate the development of urban transport policy over the next four decades [21]. For example, do in-store shopping activities and travels leads to the greater use of motorised transport modes? This issue may demonstrate how types of activity and travel could explain the significant contribution of carbon emission from the transportation sector.

In fact, the study of shopping activities and travel behaviour is not new. It has a long-standing theory and empirical evidence, as can be seen in the literature. Most studies employed empirical data from developed countries or assumed logical thinking with the background of developed countries point of view or environment. It raised a hypothesis whether individuals in developed countries will have perfectly similar behaviours with their counterparts in developing countries. With a fact of the 
difference in many facets of societal, political, cultural, and infrastructure background between the two, it is fair to question the similarity of the behaviour. The question becomes more relevant when the influence of ICT is considered. The wide and massive effect of ICT is questioned whether it changes an individual's behaviour. For example, there are things that can be learned from years of research about transport effects of e-commerce as reported by Rotem-Mindali and Weltevreden [22]. Exploring the participation in in-store shopping travel and activity is substantial, especially in developing countries; this is due to several factors, such as (i) limited level of trust between shoppers and buyers when trading products; (ii) limited access to, and infrastructure for, ICT to conduct online shopping, and (iii) the belief that shopping is an important aspect of leisure time. Studies that integrate online and in-store travel behaviour mostly employed data from developed countries. For example, a study to develop an integrated model of activity with the store and travel mode choice was completed using data from London, UK [16]. A study to evaluate the interactions between e-shopping and traditional in-store shopping by Cao et al. [23] employed data from the Minneapolis-St Paul metropolitan area, USA. Rotem-Mindali and Salomon [24] conducted a study to develop a conceptual model of the decisions households make with regard to information gathering, purchase transactions and delivery mode using data from Tel-Aviv Metropolitan area. Therefore, this study attempts to fill the gap in the knowledge about shopping trip behaviour in the era of ICT with the background of developing country case.

The growth of online shopping platform in Indonesia in the last three years is amazing. At present, it is very easy to find an online shopping platform, such as Lazada, Bukalapak, Blibli, Tokopedia, Shopee, or JD.id, among others. The growth of these online shopping covers almost all type of goods, from food, grocery, fashion, up to furniture or even used car or house. In recent years, several brands of fashion, mall, and supermarkets offer their online platform for shopping while keep maintain their conventional store. Its attractiveness lies not only in the variety of the commodities but also the price. Shoppers can easily compare the price of one commodity with the prices provided by a series of online sellers. This platform also provides a service to contact customers and manage issues of after sales. Moreover, the growth of online shopping is supported by the online transportation services (ride-sourcing) that already expands their business from serving people movement, but now also serve to deliver all commodities bought in online shopping platform up to picking-up and sending items from one place to another. Social Media has been growing in an incremental manner in revolutionizing the way individuals communicate and do business [25,26]. This fact emphasized the crucial value of this study in investigating travel behaviour in relation to shopping activities in the era of the massive growth of online activities. Zhang and Benyoucef [27] also stated that understanding consumer behaviour in the context of social commerce has become critical to better influence consumers and harness the power of their social ties.

Therefore, important aspects of this issue are: (i) how in-store shopping behaviour influences the choice of the mode of transportation; (ii) how in-store shopping behaviour influences the arrangement of individuals' activity; and (iii) whether socio-demographics and environmental conditions influence in-store shopping behaviour. The investigation is conducted in the light of the adoption of ICT in developing country, such as online transportation services and app-based shops. The hypothesis developed from this study is that ICT may affect the way people engage in in-store shopping activities and travel. There is therefore a significant need to analyse the characteristics of in-store shoppers based on multiple factors. The integrated effects of the built environment, socio-demographic aspects and ICT on the frequency of and time allocated to in-store shopping trips should also be carefully examined. A reasonable hypothesis, for instance, is that in-store shopping travel and activity behaviours are likely to be determined by the type of built environment and the accessibility of shopping stores. Trip-chaining behaviour is also likely to be used as a way of managing trips under time and space constraints.

Based on a dataset collected in Bandung Metropolitan City (Indonesia) in 2017, this study aims to segment in-store shoppers on the basis of multiple factors and to explain the determinants of in-store 
shopping travel and shopping behaviour. The process of segmentation analysis is carried out in two stages. A cluster analysis is first performed using the characteristics of the built environment, and following this, a discriminant analysis is conducted in order to profile the mode of transport chosen by the respondents based on the cluster analysis of the built environment, trip chaining, ICT experience, and socio-demographics. The final analysis uses a set of multivariate analysis to explain the factors that encourage or discourage shopping trip engagement and time allocation.

\section{Travel Patterns in In-Store Shopping Activities}

\subsection{Characteristics and Attractiveness of In-Store Shopping}

Shopping is widely accepted as a heterogeneous class of activities when modelling behaviour (Mokhtarian [13], Visser and Lanzendorf [28], Rotem-Mindali and Salomon, [24] Girard et al. [29], Suel and Polak [16]). Shopping for daily groceries may involve different behavioural mechanisms with different mobility implications when compared to occasional shopping for white goods items [16]. In-store shopping as a part of daily life enables individuals both to acquire certain items and to fulfil needs for social interaction and entertainment. Individuals also maximise their daily trip chain by include shopping activities in their trips [13]. Prior work has shown that underlying these shopping behaviours are several fundamental motivations involving the fulfilment of certain needs or desires [30]. These needs and desires vary between individuals, and Tauber [31] has underlined the personal and social motivation aspects of these. Personal motivation consists of personal physical and physiological needs, such as acquiring items, diversions from the daily routine, and personal satisfaction, including following the latest trends, fashions and innovations. Social motivation has also been shown to be an aspect related to the fulfilment of social interactions, such as social experiences outside the home, communication, attaining status, and getting pleasure from bargaining [31].

The changes to daily life in the digital era because of the development of ICT have altered the ways in which people carry out activities, including shopping activities. Mokhtarian [13], Hsiao [14], Mokhtarian and Salomon [15], and Schmid and Axhausen [2] have reported on the effects of ICT on shopping and travel behaviour. The e-commerce does not only give implications on people mobility, but also on complementary side, namely freight transport [22]. These studies highlighted that ICT does not necessarily replace all in-store shopping or other trips, and concluded that: (i) only certain factors related to social and personal motivation can be replaced by ICT services (for example, the latest trends, fashions and innovations) while others cannot (for example, social interactions); and (ii) rates of in-store shopping remain solid, attracting individuals in certain sectors of goods (for example, groceries) [32,33].

Tauber [31], Gould and Golob [34], Salomon and Koppelman [1], and Mokhtarian [13] have explained the attractions of in-store shopping travel and shopping activities. It has been argued that one advantage of in-store shopping activity is the power of physical contact to create sensory information by seeing, trying, feeling, smelling, tasting or manipulating the desired items, providing individuals with full information about and confidence in the product [35]. Secondly, it has been found that a lack of trust is a barrier to online shopping. For instance, individuals tend to choose established stores with many years of trading in their town rather than e-shopping retailers, who are unknown and may go out of business without warning [36]. Lastly, the instant possession of items is important; individuals can immediately own the purchased items, rather than waiting for the items to be delivered after e-shopping [37].

In addition to the dimension of competitiveness of in-store shopping as opposed to e-shopping, external components of the in-store shopping process also have substantial influence. Shopping as a physical activity provides opportunities to meet needs for social engagement, since going shopping offers time to enjoy oneself, either alone or with friends and family [34]. In-store shopping can also be an entertainment activity, rather than solely a maintenance activity. The function and facilities provided by modern stores (e.g., restaurants, theatres, cafés, etc.) present positive opportunities for 
enjoying in-store shopping [1]. Furthermore, some shopping trips form part of trip chains for other purposes [13,38].

\subsection{Travel Patterns}

Individual behaviour aiming to fulfil needs and desires manifests in certain activity and travel patterns under the constraints of time and space [39]. Daily activities (mandatory or discretionary) require individuals to make decisions about the location, participation, timing, and duration of their activities $[40,41]$. Simultaneously, the decision by each individual to plan a trip affects the duration of the activity [42], while the duration of the trip is influenced by transport quality. In the field of shopping activities, the nature of retailing activity has implications for travel in general and more specific for personal mobility [16]. Shopping travel duration has negatively associated with duration for out-of-home maintenance activity and travel [43]. The decision manifests in the regularity to visit shops and purchase behavioural characteristics [5], where it may also be driven by household heterogeneity and their shopping objectives and/or motivations. Various needs and desires among individuals result in diverse activity arrangements and travel patterns, and this is a topic that has attracted many researchers, for example Levinson and Kumar [44], Kitamura et al. [45], and Axhausen et al. [46]. Although travel is still accepted as derived demand, the recognition of the "positive utility of travel" is growing with the changing nature of the environment, economy, and technology [15]. Therefore, the complex factors influencing travel patterns arise from the individuals' reaction to these changes, where the decision materialised in activity in a destination, activity during travel, and travel as the activity itself. An individual's travel arrangements are therefore more complex than a single episode.

Since individuals arrange daily trips for multiple purposes and to numerous locations, these trips typically take the form of a trip chain $[8,9,47-50]$. A daily trip chain arrangement can be very stable or very random from time to time. Trip chain stability is generally influenced by the individuals' patterns or habits of activity and their socio-demographic characteristics [51,52]. The complex changes to individuals' routines and their environments determine the variability of these trip chains, as individuals tend to spread their risk, satisfy their curiosity, and are affected by other external influences. Therefore, the travel pattern may be rigidly unchanging $[53,54]$ or may never be exactly repeated from one day to the next [41]. Moreover, travel pattern also manifested in their rhythm, namely in its regularity and frequency [10]. Individual differs both in their regularity (erratic or regular) as well as the frequency of shopping activity participation, where the individual and spousal employment-related attributes, travel mode used for shopping, and trip-chaining behaviour have a strong influence on shopping frequency [11]. Moreover, the pattern of travel to support shopping activities should be interpreted with the fact of the variability. Differences across individuals in the variations of their shopping travel patterns across days by treating the day-of-the-week evolution of shopping travel patterns as a stochastic process and quantified characteristics of diversification for respective individuals [12]. For example, Kim and Park [5] found that routine shoppers are identified as having a high opportunity and search costs, which are represented by five demographic variables.

Moreover, land use plays an important role in the spatial-temporal constraints on individuals. Urban form, through the structure and characteristics of the built environment, can influence the way in which individuals participate in activities, because of its interaction with the location of the activity [55]. The causal link between built environments and travel behaviour has been given substantial attention by numerous researchers, for example McNally and Ryan [56], Kitamura et al. [57], Ewing and Cervero [55], Reilly and Landis [58], Schwanen and Mokhtarian [59], Handy et al. [60], and Cao et al. [61]. However, few studies have considered the context of developing countries. Since different causal mechanisms are highly likely to apply, depending on the combination of the individual's preferences and the type of environment in which he or she lives [62], the results from different cases might provide valuable insight. Prior studies have also indicated the importance of 
individuals' motivations in meeting their needs (i.e., shopping activities by individuals and households in the developing world).

Furthermore, it is obvious that the travel pattern in the era of ICT is also influenced. ICT's impacts cover trip/activity generation, destination, mode, and route choice, execution time and duration, and automobile ownership [63]. The literature reports different findings as the definition, context, sample, and methodology are, in fact, various. Thus, a single conclusion is difficult to achieve and far from trivial, and heavily depends on the definition, assumptions, and methodology [22]. In order to advance the study regarding the interaction of ICT and travel behaviour, Cao [64] evaluated the progress to understand the connections between e-shopping, spatial attitudes, and travel behaviour. Rotem-Mindali and Weltevreden [22] also conducted a study to review extensively the conceptual and quantitative studies on the implication of e-commerce on mobility including its complementary side, namely freight transport. Several pieces of literature can be referred to which provide concise and consistent results. Suel and Polak [16] revealed smaller stores and longer travel distances being associated with declining utilities, agglomeration and competition significantly influencing store choice. Cao et al. [23] reported that the marginal effects of online-buying frequency and online-searching frequency on in-store shopping frequency were 0.153 and 0.189 , respectively. Hubers et al. [65] showed that positive relations between ICTs and activities fragmentation were mostly found, though these relations differ for the kind of ICT and kind of activity investigated. The frequency of online searching before deciding to do in-store shopping has a positive influence on the frequency of in-store shopping [66]. A shopper who is a frequent online buyer is associated with more trips to stores for both daily and nondaily goods, and shorter stay for nondaily goods [67]. Farag et al. [33] also found that the frequency to visit a store has a positive effect on frequency to shop online. Zmud et al. [68] found that trip rates of Internet shoppers were higher than shoppers of non-Internet. Ferrell [69] reported that teleshopping frequency has a positive association with shopping trip frequency and trip chaining, but it does not have a significant influence on shopping travel distance. Teleshopping frequency is negatively associated with total travel distance, but positively associated with total trip frequency [69]. Duration for teleshopping has a negative association with shopping travel time, distance, and frequency. As a matter of fact, all of these studies were conducted using data from developed countries, namely London, UK [16], Minneapolis-St. Paul metropolitan area, USA [23], the Netherland [32,33,65-67], Sacramento, USA [68], San Fransisco, USA [69,70], and Portland, USA [43]. For the knowledge of the authors up to present, there are few studies that aim at investigating specific relationships between ICT's use and travel behaviour. One from very limited is a study by Lila and Anjaneyulu [71] that studied the participation of Bangalore urban dwellers in virtual activities through mobile phone or internet and the impact of ICT usage on activity and travel behaviour in the Indian context, which is not specific in shopping-related activities. Therefore, this study has the potential in fill the gap to improve knowledge of shopping travel behaviour in a developing country.

\section{Method}

\subsection{Data Collection}

This study used a questionnaire, which was distributed to households in Bandung City, Indonesia to collect data on individuals' shopping behaviour. The questionnaire was constructed based on prior literature on in-store shopping activity, travel behaviour and the built environment. It consisted of socio-demographic aspects (e.g., income, family status, home status, etc.), grocery shopping behaviour including spatial location, shops, and travel characteristics, and the characteristics of the built environment. This survey only collected cross-sectional report about their most typical shopping activity without reporting travel diary. Only one person in each household was asked as a representative of the household to fill in the questionnaire. The person who filled in the questionnaire was not necessarily the person who carried out the shopping activity. A pilot survey was also conducted using 37 respondents. 
The questionnaire was distributed in six administrative areas of Bandung City: Tegallega, Gede Bage, Ujung Berung, Karees, Cibeunying, and Bojonagara. This offline survey was conducted between 10th and 16th June 2017, with the help of 27 surveyors to collect responses from households using paper and pencil. A sample size of 400 was determined using Yamane's equation [72,73]. According to Yamane [72], the total number of sample size can be calculated as follow:

$$
n=\frac{N}{1+N(e)^{2}}
$$

where $n=$ corrected sample size; $N=$ population size, and $e=$ Margin of error. Therefore, for the context of this study, the total population of Bandung, is 2,481,469 inhabitants [74], and used a 5\% significance level. This sample size was increased to 520 in anticipation of errors arising during the survey. The sample was not collected purely at random, since the surveyors needed to select the targeted household based on their income level. It can be stated that the sampling process is purposive sampling. Based on initial observation about the targeted area, the surveyors were able to select suitable households based on the income level groups. Using personal approach and appropriate time of visit when visiting the targeted household, the response rate of this survey was quite high, i.e., more than $90 \%$. The rejection rate was very low since anyone in the household could respond to the survey. The help of surveyors in explaining the question and sometimes writing down the answers increased the success rate of the survey. An appreciation gift was also provided for each respondent who completely filled in the questionnaire. After reviewing all completed questionnaires, the responses were analysed.

\subsection{Characteristics of Respondents}

The results presented in Table 1 show that the majority of respondents used a motorcycle (41.1\%) for shopping travel, while $29.4 \%$ of the respondents used non-motorised transport (NMT). The figure of mode usage is in line with the distribution of transport mode in Bandung City in 2013 [74] that there were 1.04 million units of motorcycle (72.16\%) and 0.33 million units of car (22.87). The majority of the respondents were older than 35 years of age (62.7\%). According to the report of Statistics of Bandung City in 2016 [75], the distribution of age group in Bandung shows a significant proportion of young people (31.89\% for the age of younger than 19 years old and $10.42 \%$ for $20-24$ years old). The age group of 25-39 years old has a proportion of $25.75,40-49$ years old $21.87 \%$, and older than 50 years old $18.00 \%$. This study has a lower representation of young people, since the persons who answered the questionnaire were naturally persons with enough capability to report their activities. Other age groups seem as able to be represented. The monthly household income with less than three million IDR has a proportion of $33.4 \%$ and $29.3 \%$ of the respondents had an income in the range of three to six million IDR. The survey also found $15.2 \%$ of respondents with an income of more than twelve million IDR, representing the middle-upper class. As a reference, the monthly minimum wage for the region of Bandung is three million IDR. At the time of study, 1 USD was equivalent to 13,500 IDR. By referring to the cost of living in Bandung City for 2012, the average of cost of living in Bandung is 5.4 million IDR [76]. Therefore, from the characteristics of respondent and comparison with the reported data about the population (Bandung City), it can be judged that this study has a good representation of the population.

Moreover, referring to Strathman and Dueker [77], our study defined multi-trips as those that contained a shopping trip as only one of several other trips, while a single trip was defined as consisting of a shopping trip as the sole purpose. Table 1 shows that all of the travel characteristics differ significantly between multi- and single trips, including the types of vehicle ownership. Mode share and income also show differences for these two types of travel. 
Table 1. Respondent Characteristics.

\begin{tabular}{|c|c|c|c|c|}
\hline \multicolumn{2}{|c|}{ Variables } & \multirow[b]{2}{*}{$\%$} & \multicolumn{2}{|c|}{ Chi-Square (Sig.) } \\
\hline Varia & oles & & ST vs. MT & $\begin{array}{l}\text { Own vs. Not-Own } \\
\text { Private Car }\end{array}$ \\
\hline \multirow{4}{*}{ Modes } & Motorcycle (MC) & 41.07 & \multirow{4}{*}{$20.970(* *)$} & \multirow{4}{*}{$16.818\left(^{* *}\right)$} \\
\hline & Private Car (PC) & 18.45 & & \\
\hline & $\begin{array}{l}\text { Public Transport } \\
\text { (PT) }\end{array}$ & 11.11 & & \\
\hline & NMT & 29.37 & & \\
\hline \multirow{5}{*}{ Age } & $<18$ years old & 1.56 & \multirow{5}{*}{$8.558\left(^{*}\right)$} & \multirow{5}{*}{$8.431(*)$} \\
\hline & 18-25 years old & 15.04 & & \\
\hline & 26-35 years old & 20.70 & & \\
\hline & $36-50$ years old & 40.43 & & \\
\hline & $>50$ years old & 22.27 & & \\
\hline \multirow{5}{*}{ Household Income } & $<3$ million IDR & 33.40 & \multirow{5}{*}{$19.670(* *)$} & \multirow{5}{*}{$41.347(* *)$} \\
\hline & 3-6 million IDR & 29.32 & & \\
\hline & 6-9 million IDR & 13.79 & & \\
\hline & 9-12 million IDR & 8.20 & & \\
\hline & $>12$ million IDR & 15.30 & & \\
\hline
\end{tabular}

$\mathrm{n}=520 ;{ }^{*} \rightarrow$ Significant at $10 \% ;{ }^{* *} \rightarrow$ Significant at $5 \%$; ST $=$ single trip; MT $=$ multi-purpose trip.

\section{Data Analysis}

\subsection{Models for Shopping Behaviour}

Previous studies have underlined the importance of mode choice as an instrument of accessibility to a shopping location and its substantial interaction with total shopping cost. Studies also investigated the destination, frequency, and commodities in shopping activities, where many studies employed discrete choice models. For example, Richards and Ben-Akiva [7] conducted a study about developing a disaggregate simultaneous destination and mode choice model for shopping trips using multinomial logit model (MNL). Arentze et al. [8] proposed a multi-purpose trip model as a way to improve conventional MNL in experimenting destination choice. Bacon [10] developed an algorithm of utility-maximising model to calculate the optimal frequency of shopping. Baker [9] employed quadratic regression between bonding of consumers to a particular shopping centre and the number of retail outlets as well as between mean trip frequency and the number of retail outlets in a planned suburban shopping centre. Bhat [7] developed a model structure that combined multinomial logit (MNL) form for the higher-level mode choice decision and standard ordered generalized extreme-value (OGEV) form for the lower-level departure time choice decision. Kim and Park [6] proposed a mixture model of the exponential and the Erlang-2 distribution with heterogeneous frequency for shopping trip intervals when they investigated shopping trip regularity and shopping frequency. Bhat et al. [11] applied the methodology of hazard-based duration model to model inter-shopping duration and latent segmentation method to distinguish between erratic shoppers and regular shoppers using a continuous six-week travel survey. Suel and Polak [16] proposed a more advanced model by integrating destination and mode choice models with online channels in a unified framework using multinomial logit and nested logit estimations.

In the present study, the proposed models were designed based on the theoretical model of a shopping trip, which was developed by Bawa and Ghosh [78]. We also performed a classification analysis or discriminant analysis [79] to investigate the segmentation of shopping behaviour based on the choice of mode of transport to the shopping location. This analysis aimed to investigate how individuals arranged their shopping activity within their daily trip chain. A set of multivariate analyses were then carried out to explain those factors that encouraged or discouraged the decision to engage in a shopping trip. Socio-demographic and shopping-related variables were included in the models 
to test a hypothesis related to the rationality of consumer behaviour. The study examined whether households tend to maximise the utility of their journey by planning their travel and by trading this off against total cost, mode choice, and trip arrangement.

These methodologies were selected as the multivariate methods has the flexibility that made it possible to employ a different type of methods in this series of analyses. The flexibility to do several different methods was needed as the choice in this study was not purely available. In other words, it is hypothesised that the choice seems as a constraint for other decisions where it made complex decisions or causal relationships among variables. Therefore, it can be judged that the method is suitable to do the segmentation of the shoppers, exploration of the characteristics, and investigation of the determinants factors. The other reason was strengthened by the motivation to do an analyses to provide different and hopefully new insights about the in-store shopping activities in developing countries. With its simplicity in methodology, then, the study can be used to pave the way in investigating shopping trips behaviours and be followed by other researchers in developing countries. The accumulation of findings from several places in developing countries will be useful for comparison with the previous study and to continue with further analysis (such as discrete choice model to elaborate policy scenarios using stated preference methods).

\subsection{Latent Variables of the Built Environment}

We explored the effects of the built environment on shopping activity and travel behaviour. A total of 18 attributes related to aspects of the built environment were introduced using a five-point Likert-scale (ranging from $1=$ strongly disagree to $5=$ strongly agree). An exploratory factor analysis was conducted to find the level of influence of the variables by removing sources of covariance and measurement noise. The findings were analysed further by including the mode choice and activity allocation models [2].

We applied principal component analysis with orthogonal varimax rotation as a way to provide the most adequate information for the variables under examination and simplify the factor structure. Factor loadings of lower than 0.5 were removed as values for practical significance, as suggested by Hair et al. [79]. The value of the Kaiser-Meyer-Olkin sampling adequacy test was higher than 0.8 , indicating that the sum of partial correlation is small relative to the sum of the population. This shows that factor analysis is an appropriate method to use in this context $[80,81]$. Similarly, the value of Bartlett's sphericity test was significant (smaller than 5\%), and that the hypothesis that the original correlation matrix is an identity matrix was rejected. The variance explained $59.7 \%$ of the data, meaning that all parameters can be accepted for further interpretation. Table 2 shows the main findings. The variables can be reduced to five factors: (i) high accessibility; (ii) a green environment; (iii) a secure environment; (iv) high levels of social interaction; and (v) NMT friendliness. These five factors represent the built environment conditions of the home location of the shoppers. High accessibility indicates that shoppers have good access to several important locations and facilities; a green environment denotes that shoppers live in green neighbourhoods; a secure environment refers to safety issues relating to the areas between homes and shopping locations; high levels of social interaction means that shoppers can easily socialise with others; and lastly, NMT friendliness indicates good access to NMT infrastructure.

\subsection{Classification Model for Mode Choice}

The mode choice behaviour for shopping activity was analysed by applying discriminant analysis to explore the profiles of the respondents who made these grocery shopping trips. The reported mode choice used to support shopping activities was the most typical mode used by shoppers to reach the most frequent visited grocery store. It implied a fact that the reported mode was a representative mode for the most frequent shopping activity which did not depend on different day or context. The results are presented in Table 3, where the model evaluations followed Hair et al. [79] and Burns and Burns [82]. The analysis was completed with the group of three modes as the dependent variable, 
and socio-demographics, travel and the built environment as the independent variables. A sample size of 520 and 15 independent variables resulted in a ratio of cases to independent variables of more than 5:1, as suggested by Hair et al. [79]. The result of Box's M test showed that the null hypothesis (with equal population covariance matrices) was rejected. When using Box's $\mathrm{M}$ test, a non-significant value of $\mathrm{M}$ is expected if the variance and covariance matrices are equivalent; however, with at large sample, a significant result is not regarded as the problem [82].

Table 2. Factor Analysis of Built Environment.

\begin{tabular}{|c|c|c|c|c|c|}
\hline My Home Environment Have .... . & $\begin{array}{c}\text { High } \\
\text { Accessibility }\end{array}$ & $\begin{array}{c}\text { Green } \\
\text { Environment }\end{array}$ & $\begin{array}{c}\text { Secure } \\
\text { Environment }\end{array}$ & $\begin{array}{l}\text { High Social } \\
\text { Interaction }\end{array}$ & NMT Friendly \\
\hline Easy access to shopping place & 0.668 & & & & \\
\hline Easy access to public facilities & 0.745 & & & & \\
\hline Easy access to city centre & 0.785 & & & & \\
\hline Easy access to main road & 0.738 & & & & \\
\hline Easy access to public transport & 0.557 & & & & \\
\hline Bicycle route available & & & & & 0.757 \\
\hline Pedestrian route available & & & & & 0.765 \\
\hline Parks and green space available & & 0.652 & & & \\
\hline Quiet environment & & & 0.698 & & \\
\hline Sufficient street lighting & & & 0.579 & & \\
\hline Low crime rate & & & 0.687 & & \\
\hline Low vehicle traffic & & & 0.692 & & \\
\hline Lots of people outside neighbourhood & & & & 0.845 & \\
\hline Lots of people inside neighbourhood & & & & 0.862 & \\
\hline High social interactions & & & & 0.549 & \\
\hline Large garden in front/back & & 0.726 & & & \\
\hline Parking space available & & 0.668 & & & \\
\hline Well maintained & & 0.717 & & & \\
\hline
\end{tabular}

Method: Principal Component Analysis with Orthogonal Varimax Rotation with Kaiser Normalization; Kaiser-Meyer-Olkin measure of sampling adequacy: 0.808; Variance explained: 59.7\%; Bartlett's Test of Sphericity [x2; df.; p-value]: [2442.234; 153; 0.000]; * Loadings smaller than 0.500 were suppressed [79].

The mode choice variables were private car (PC), motorcycle (MT), public transport (PT) and NMT (e.g., walking or bicycling). The interpretation of the models depends on the function of group centroid, which separates two choices by observing the most positive value and the most negative value of each function. Function 1 separates respondents who travelled with NMT (1.294) from respondents who travelled with PC (-1.775). Function 2 separates users with PC (0.553) from respondents with PT (-0.939), while the third function separates travellers using MT (0.301) from travellers using PT $(-0.569)$.

According to the values of the structural matrix, the predictor variables strongly associated with discriminant Function 1 are shopping expenditure, the distance of shopping location, household expenditure, travel cost and time, and the green environment latent variable. The model shows that shopping expenditure influences the choice of travel mode. Shoppers who spend less than 100,000 IDR (less than 8 USD) are more likely to walk or bicycle to reach a shopping location than to use a private car. In contrast, shoppers who spend more than 250,000 IDR (around 18 USD) tend to use a private car rather than walking or bicycling. Function 1 also shows that shoppers who walk or bicycle to reach a shopping location tend to have a travel cost of less than 10,000 IDR (less than 1 USD) and a travel time of fewer than 10 minutes. Meanwhile, shoppers who use a private car tend to come from families with medium-to-high household expenditure (more than 3 million IDR per month). This finding supports previous findings on the strong relationship between income and mode availability of private car. Interestingly, the results also confirmed that shoppers who live in green environments tend to use private cars, since this type of residential area is quite limited and tends to be more expensive.

The second function of the model is partially confirmed by the findings from the first. This reveals the effect of the socio-demographics of respondents who used a private car or public transport. The results show that shoppers who spend more than 250,000 IDR are more likely to use a private car than public transport. In this function, shopping trips and activity behaviours are not significant in distinguishing the two groups. 
The third function distinguished between the choices of motorcycle and public transport. It was found that shoppers who use public transport tend to have travel costs of less than 10,000 IDR and have good access to public transport facilities. Shoppers who use motorcycles are associated with the availability of private modes of transport in their households.

The analysis suggests that shoppers treat shopping expenditure relatively equally across the available modes when making a decision to travel for shopping purposes. This means that the characteristics of the shopping activity (such as the number of products) will affect the decision on transport mode. This model confirms that shoppers carefully examined constraints related to shopping activity and travel characteristics.

Table 3. Classification Analysis of Mode Choice.

\begin{tabular}{|c|c|c|c|c|c|c|c|c|c|}
\hline \multirow{2}{*}{ Variables } & \multicolumn{4}{|c|}{ Dependent Variables Group Means } & \multirow{2}{*}{$\mathbf{F}$} & \multirow{2}{*}{ Sig. } & \multicolumn{3}{|c|}{ Structural Matrix } \\
\hline & MT & PC & PT & NMT & & & F1 & F2 & F3 \\
\hline Shopping expenses $\leq 100.000$ IDR [D] & 0.274 & 0.023 & 0.208 & 0.704 & 58.583 & 0.000 & $0.562 *$ & 0.336 & -0.075 \\
\hline Shopping expenses $=250.000$ IDR [D] & 0.188 & 0.540 & 0.113 & 0.028 & 38.341 & 0.000 & $-0.452 *$ & 0.296 & 0.030 \\
\hline Trip distance $<1 \mathrm{~km}[\mathrm{D}]$ & 0.435 & 0.172 & 0.283 & 0.866 & 57.349 & 0.000 & 0.547 * & 0.398 & 0.099 \\
\hline Only Shopping Trip (ST) [D] & 0.753 & 0.655 & 0.698 & 0.894 & 7.202 & 0.000 & 0.195 * & 0.130 & 0.051 \\
\hline Monthly Expenditure $\geq 3$ million IDR[D] & 0.156 & 0.586 & 0.019 & 0.106 & 42.108 & 0.000 & -0.403 & $0.620 *$ & -0.015 \\
\hline House area $\geq 150 \mathrm{~m}^{2}[\mathrm{D}]$ & 0.183 & 0.425 & 0.094 & 0.099 & 1.600 & 0.189 & -0.269 & 0.271 * & 0.073 \\
\hline Owned Private Vehicle [D] & 0.995 & 0.989 & 0.906 & 0.986 & 6.266 & 0.000 & 0.000 & 0.243 & $0.574 *$ \\
\hline Travel cost $\leq 10.000$ IDR [D] & 0.780 & 0.644 & 0.906 & 0.993 & 20.364 & 0.000 & 0.327 & -0.024 & -0.401 * \\
\hline Travel time $\leq 10$ minutes [D] & 0.876 & 0.609 & 0.830 & 0.965 & 20.552 & 0.000 & $0.332 *$ & -0.150 & 0.261 \\
\hline Travel time $\geq 45$ minutes [D] & 0.000 & 0.046 & 0.000 & 0.007 & 4.423 & 0.004 & -0.111 & 0.231 * & -0.169 \\
\hline High Accessibility & -0.122 & 0.093 & 0.154 & 0.103 & 2.176 & 0.090 & 0.012 & 0.085 & -0.390 * \\
\hline Green Environment & 0.098 & 0.548 & -0.114 & -0.399 & 18.991 & 0.000 & $-0.326 *$ & 0.043 & 0.232 \\
\hline Secure Environment & -0.096 & 0.001 & -0.022 & 0.114 & 1.195 & 0.311 & 0.045 & 0.114 & -0.172 * \\
\hline High Social Interaction & 0.074 & -0.207 & -0.032 & 0.062 & 1.786 & 0.149 & 0.082 & -0.081 & 0.181 * \\
\hline NMT Friendly & -0.079 & 0.216 & 0.150 & -0.079 & 2.437 & 0.064 & -0.092 & 0.025 & $-0.280 *$ \\
\hline Goodness-of-Fit Parameters & \multirow{2}{*}{\multicolumn{4}{|c|}{$977.845[7.539 ; 120 ; 104934.596 ; 0.000]$}} & \multirow{5}{*}{$\begin{array}{l}\text { Function } \\
\text { of } \\
\text { Group } \\
\text { Centroid }\end{array}$} & Mode Choice & F1 & F2 & F3 \\
\hline Box's M [F;df1;df2; $p$-value] & & & & & & MT & -0.118 & -0.290 & 0.301 \\
\hline Eigen Values [Canonical Correlation] & \multicolumn{4}{|c|}{$1.111 ; 0.239 ; 0.080[0.725 ; 0.439 ; 0.272]$} & & PC & -1.775 & 0.553 & -0.135 \\
\hline Wilks' Lambda F1 through F3; F2 through F3; & \multicolumn{4}{|c|}{$0.354 ; 0.747 ; 0.926[0.000 ; 0.000 ; 0.001]$} & & PT & -0.138 & -0.939 & -0.569 \\
\hline $\begin{array}{l}\text { F3[ } p \text {-value] } \\
\text { Percent Correct }\end{array}$ & \multicolumn{4}{|c|}{$62.40 \%$} & & NMT & 1.294 & 0.392 & -0.100 \\
\hline
\end{tabular}

Note: MT: Motorcycle, PC: Private Car, PT: Public Transport, NMT: Non-Motorised Transportation (e.g., walking and bicycling); *: Largest absolute correlation between variable and any discriminant function; $[\mathrm{D}]=1$ yes; 0 otherwise.

\subsection{Classification Analysis of Shopping Activity Allocation}

An analysis was performed to investigate the types of shopping activity allocation, either as single trips or multi-trips. The results are presented in Table 4. Goodness-of-fit parameters confirm the acceptability of the model and its ability to correctly classify $64 \%$ of the respondents. The value of Wilks' lambda indicates that the function is highly significant. The ratio of cases to independent variables confirms the acceptability of the model, as it is higher than 5:1 for 520 respondents with 11 dependent variables.

The model differentiates between shoppers using a single trip (ST) and those using a multi-purpose trip (MT). The results show that ST shoppers were strongly associated with certain travel and shopping characteristics. Shoppers who spent less than 100,000 IDR when shopping were more likely to conduct an ST. These ST shoppers had a travel distance of less than $1 \mathrm{~km}$ and a travel time of 10 minutes. The model reveals the tendency of ST shoppers to walk or bicycle to reach the shopping location, and shows that senior citizens had a strong tendency to use an ST when visiting a shop. This finding reveals details of the shoppers' arrangements for travel mode and cost, the amount spent on shopping, and their activities. Function 1 also shows that MT shoppers had a strong association with a travel distance of more than $10 \mathrm{~km}$ and a travel cost of more than 40,000 IDR to reach the shopping location, thus confirming the mechanism whereby individuals arrange their trips in the form of a trip chain as a way to manage travel length and cost. 
Table 4. Classification Analysis of Shopping Activity Allocation.

\begin{tabular}{|c|c|c|c|c|c|}
\hline \multirow[t]{2}{*}{ Variables } & \multicolumn{2}{|c|}{$\begin{array}{c}\text { Dependent Variables } \\
\text { Group Means }\end{array}$} & \multirow[t]{2}{*}{$\mathbf{F}$} & \multirow{2}{*}{ Sig. } & \multirow{2}{*}{$\begin{array}{c}\begin{array}{c}\text { Structural } \\
\text { Matrix }\end{array} \\
\text { F1 }\end{array}$} \\
\hline & ST & MT & & & \\
\hline Shopping expenses $\leq 100.000$ IDR [D] & 0.379 & 0.257 & 5.332 & 0.021 & 0.341 \\
\hline Travel distance $\leq 1 \mathrm{~km}[\mathrm{D}]$ & 0.553 & 0.314 & 19.314 & 0.000 & 0.648 \\
\hline Travel distance $\geq 10$ km [D] & 0.011 & 0.057 & 8.536 & 0.004 & -0.431 \\
\hline Travel time $\leq 10$ minutes [D] & 0.869 & 0.781 & 5.008 & 0.026 & 0.330 \\
\hline Travel cost $\leq 10.000$ IDR [D] & 0.845 & 0.790 & 1.721 & 0.190 & 0.193 \\
\hline Travel cost $\geq 40.000$ IDR [D] & 0.014 & 0.048 & 4.575 & 0.033 & -0.315 \\
\hline Age $\geq 50$ years Old $[\mathrm{D}]$ & 0.253 & 0.143 & 5.699 & 0.017 & 0.352 \\
\hline PT user & 0.101 & 0.152 & 2.178 & 0.141 & -0.218 \\
\hline NMT user & 0.354 & 0.143 & 17.708 & 0.000 & 0.621 \\
\hline High accessibility & 0.036 & -0.076 & 1.088 & 0.297 & 0.154 \\
\hline Secure environment & 0.039 & -0.181 & 4.037 & 0.045 & 0.296 \\
\hline Goodness-of-Fit Parameters & \multirow{2}{*}{\multicolumn{2}{|c|}{$\begin{array}{l}298.575[4.345 ; 66 ; \\
122693.135 ; 0.000]\end{array}$}} & \multirow{5}{*}{$\begin{array}{c}\text { Function } \\
\text { of } \\
\text { Group } \\
\text { Centroid }\end{array}$} & Trip & \multirow{2}{*}{$\mathrm{F} 1$} \\
\hline Box's M [F; df1; df2; $p$-value] & & & & Chain & \\
\hline Eigen Values [Canonical Correlation] & \multirow{2}{*}{\multicolumn{2}{|c|}{$\begin{array}{l}0.098[0.298] \\
0.911[0.000]\end{array}$}} & & ST & 0.167 \\
\hline Wilks' Lambda F1[ $p$-value] & & & & MT & -0.583 \\
\hline Percent Correct & \multicolumn{2}{|c|}{$64.0 \%$} & & & \\
\hline
\end{tabular}

\subsection{Classification Analysis of Interaction between Mode Choice and Shopping Activity Allocation}

The findings from the previous analyses reveal a strong association between mode choice and shopping activity allocation behaviours. Further exploration was performed using a two-step analysis to examine the interaction and the segmentation between both variables. This two-step method followed the work of Satish and Bharadhwaj [83] in delineating groups that differ in terms of criterion variables and in establishing significant relationships between the groups. This method is suitable when categorical variables with three or more levels are involved in the analysis.

Based on the analyses discussed in Sections 4.2 and 4.3, it was found that there were four options for mode choice (i.e., PC, MC, PT, and NMT) and two levels of activity allocation (i.e., ST and MT). Using these classifications, the first step of the cluster analysis aimed to identify the combined group of mode of transport and activity allocation. The results showed an optimum level of six clusters for 520 respondents. The proportions for each cluster are presented in Table 5.

Table 5. Cluster Analysis of Mode Choice and Shopping Activity Allocation.

\begin{tabular}{ccc}
\hline No & Cluster Name & Proportion of Total Respondents (\%) \\
\hline 1 & NMT user with ST & 26.2 \\
2 & PC user with MT & 12.9 \\
3 & MC user with ST & 10.1 \\
4 & MC user with ST & 31.0 \\
5 & PT user with ST & 7.5 \\
6 & PC user with ST & 12.3 \\
\hline Size of [Smallest Cluster: Largest Cluster] & {$[7.5: 31.0]$} \\
Ratio of Smallest Cluster and Largest Cluster & 4.1 \\
\hline
\end{tabular}

The second step aimed to investigate the interactions between the variables of mode choice and shopping activity allocation, using discriminant analysis. Using the six clusters as dependent variables in the second step, our analysis was able to find five functions, as shown in Table 6 . While the model was able to correctly classify $39.6 \%$ of the respondents, the values for Wilks' lambda indicate 
insignificance for the cases of function four through function five and function five. The structure matrix can be interpreted in a similar way to the factor loadings, which show the correlations of each variable with each discrimination function [82]. Attributes with loadings higher than 0.3 are used for interpretation.

The first function separates ST shoppers who used NMT (1.122) from those who used a PC $(-1.349)$, while the second function differentiates ST shoppers who used a PC (0.466) from those who used PT (-1.071). Function 3 separates respondents who used an MC during an MT (0.486) and PT for a ST (-0.576). Function 4 differentiates between car users who undertook STs and MTs. The last function, which separates the MT shoppers who used a PC and MC, will not be interpreted, as this was determined to be insignificant.

Shoppers who spent less than 100,000 IDR were more likely to travel by walking or cycling, while those who spent more than 250,000 IDR tended to use a car, as explained by the first function. The results also show that shoppers with monthly expenses of more than 3 million IDR tended to live in green environmental areas and to own a car. The finding that a higher preference for a car was shown by people with high economic means is confirmed by the second function, which also shows the preference for the use of a car by this group, even for a shopping trip of less than $1 \mathrm{~km}$.

The third function shows that PT users for a ST were more likely to live in higher accessibility residential areas. This is understandable, since the preference to use PT depends on its accessibility. It was also found that MC users came from families with several alternative modes. Furthermore, Function 4 shows that ST shoppers were characterised by short travel distances (i.e., less than $1 \mathrm{~km}$ in distance and less than 10 minutes of travel time) and lived in green residential areas. Conversely, MT shoppers tended to have longer travel distances (greater than $10 \mathrm{~km}$ ).

\subsection{ICT Experience and In-Store Shopping Behaviour}

The significant influence of ICT on the behaviour of individuals, including shopping trips, has been acknowledged. The degree of ICT experience varies between individuals, resulting in a variety of behavioural effects. The effects of ICT may be positive, in the form of travel substitution, or may be either complementary or negative $[14,84,85]$. In this study, it is hypothesised that the degree of ICT experience of the respondent influences in-store shopping behaviour. These potential effects are tested using an ordered regression model in which the dependent variables are the frequency of in-store shopping engagement and the amount of expenditure on in-store shopping activities.

Table 7 presents the estimation results from the ordered model of shopping frequency. The goodness-of-fit test shows that the model with predictors is better than the model without independent variables. The parallel lines test shows that each group is mutually aligned. Based on these tests, the ordered model can be justified as being suitable. Moreover, in terms of statistical and practical significance, the overall model results can be said to be highly acceptable.

The variables of socio-demographics, travel characteristics and the built environment were found to significantly influence shopping frequency. Shoppers who were students or PT users tended to have a higher shopping frequency. It was also found that MT shoppers tended to have a higher shopping frequency. On the contrary, shoppers who owned a private vehicle tended to shop less frequently. In-store visitors who lived in an environment with high levels of social interaction tended to have a higher shopping frequency. The model also shows that shoppers who have no experience with online shopping tend to have a lower frequency for in-store shopping; this is also the case for shoppers who spend less than 100,000 IDR.

To gain a fuller understanding of the in-store behaviour, an ordered model with the in-store shopping expenditure as dependent variable was also estimated (Table 8). This model used the built environment, socio-demographics, travel characteristics and ICT shopping experience as explanatory variables. According to the results of the goodness-of-fit and parallel tests, the model can be justified as being suitable to explain data and as being acceptable for further interpretation. 
Table 6. Classification Analysis of Interaction between Mode Choice and Shopping Activity Allocation.

\begin{tabular}{|c|c|c|c|c|c|c|c|c|c|c|c|c|c|}
\hline \multirow{2}{*}{ Variables } & \multicolumn{6}{|c|}{ Dependent Variables Group Means } & \multirow{2}{*}{$\mathbf{F}$} & \multirow{2}{*}{ Sig. } & \multicolumn{5}{|c|}{ Structural Matrix } \\
\hline & NMT-ST & PC-MTT & MT-MTT & MT-ST & PT-ST & PC-ST & & & F1 & F2 & F3 & F4 & F5 \\
\hline Shopping expenses $\leq 100.000$ IDR [D] & 0.685 & 0.230 & 0.295 & 0.266 & 0.297 & 0.018 & 25.317 & 0.000 & $0.649 *$ & 0.100 & -0.141 & -0.103 & 0.460 \\
\hline Shopping expenses $\geq 250.000$ IDR [D] & 0.031 & 0.262 & 0.136 & 0.210 & 0.162 & 0.544 & 15.998 & 0.000 & $-0.488^{*}$ & 0.294 & -0.246 & 0.277 & -0.007 \\
\hline Travel distance $\leq 1 \mathrm{~km}[\mathrm{D}]$ & 0.862 & 0.344 & 0.273 & 0.476 & 0.297 & 0.211 & 27.821 & 0.000 & $0.648 *$ & 0.409 & -0.096 & 0.364 & -0.408 \\
\hline Travel distance $\geq 10 \mathrm{~km}[\mathrm{D}]$ & 0.000 & 0.066 & 0.045 & 0.021 & 0.000 & 0.018 & 2.161 & 0.057 & -0.101 & 0.027 & 0.207 & $-0.534 *$ & -0.207 \\
\hline Travel time $\leq 10$ minutes [D] & 0.962 & 0.705 & 0.886 & 0.874 & 0.811 & 0.684 & 7.814 & 0.000 & 0.324 & -0.092 & 0.298 & $0.406^{*}$ & 0.358 \\
\hline Travel cost $\leq 10.000$ IDR [D] & 0.992 & 0.803 & 0.773 & 0.776 & 0.865 & 0.667 & 8.653 & 0.000 & $0.369 *$ & -0.002 & -0.255 & -0.181 & 0.041 \\
\hline Monthly Expenditure $\geq 3$ million IDR [D] & 0.100 & 0.344 & 0.136 & 0.182 & 0.000 & 0.579 & 17.580 & 0.000 & -0.422 & $0.692 *$ & -0.221 & -0.077 & 0.198 \\
\hline Owned Private Vehicle [D] & 0.985 & 1.000 & 1.000 & 0.993 & 0.865 & 0.982 & 6.305 & 0.000 & 0.000 & 0.491 & $0.590 *$ & -0.193 & -0.014 \\
\hline High Accessibility & 0.103 & 0.018 & -0.206 & -0.102 & 0.144 & 0.160 & 1.468 & 0.199 & 0.019 & 0.088 & $-0.405 *$ & 0.040 & 0.073 \\
\hline Green Environment & -0.357 & 0.000 & 0.009 & 0.145 & -0.066 & 0.557 & 8.002 & 0.000 & -0.348 & 0.087 & 0.081 & $0.414 *$ & -0.045 \\
\hline Age $=25-40$ years old $[D]$ & 0.231 & 0.164 & 0.250 & 0.224 & 0.162 & 0.228 & 0.432 & 0.826 & 0.020 & 0.058 & 0.115 & 0.172 & 0.364 * \\
\hline Age $=18-24$ years old $[D]$ & 0.123 & 0.197 & 0.136 & 0.112 & 0.108 & 0.140 & 0.609 & 0.693 & -0.033 & 0.076 & -0.030 & $-0.333 *$ & -0.065 \\
\hline Goodness-of-Fit Parameters & & Trip Chain & F1 & F2 & F3 & F4 & F5 \\
\hline Box's M [F;df1;df2;p-value] & \multirow{2}{*}{\multicolumn{6}{|c|}{$\begin{array}{r}177.065[2.079 ; 78 ; 39086.463 ; 0.000] \\
9 ; 0.087 ; 0.044 ; 0.11[0.622 ; 0.360 ; 0.283 ;\end{array}$}} & & NMT-ST & 1.122 & 0.214 & -0.127 & 0.014 & 0.034 \\
\hline Eigen Values [Canonical Correlation] & & & & & & & Function & PC-MTT & -0.480 & 0.184 & -0.064 & -0.462 & -0.110 \\
\hline Wilks' Lambda F1-F2-F3-F4 through F5; F5 [ $p$-value] & \multirow{2}{*}{\multicolumn{6}{|c|}{$0.465 ; 0.759 ; 0.872 ; 0.948 ; 0.989[0.000 ; 0.000 ; 0.000 ; 0.132 ; 0.763]$}} & of Group & MT-MTT & -0.239 & -0.361 & 0.486 & -0.192 & 0.234 \\
\hline Percent Correct & & & & & & & Centroid & MT-ST & -0.152 & -0.071 & 0.265 & 0.166 & -0.091 \\
\hline & \multirow{2}{*}{\multicolumn{6}{|c|}{$39.6 \%$}} & & PT-ST & -0.143 & -1.071 & -0.576 & 0.031 & -0.013 \\
\hline & & & & & & & & PC-ST & -1.389 & 0.466 & -0.308 & 0.175 & 0.097 \\
\hline
\end{tabular}

MT: Motorcycle, PC: Private Car, PT: Public Transport, NMT: Non-Motorised Transportation (e.g., walking and bicycling); MTT: Multi Trip; ST: Single Trip; *: Largest absolute correlation between variable and any discriminant function; $[D]=1$ yes; 0 otherwise. 
Table 7. Estimation result of ordered model for in-store shopping frequency analysis.

\begin{tabular}{|c|c|c|c|}
\hline Threshold & Estimate & Wald & Sig. \\
\hline Less than once per month & -1.326 & 3.397 & 0.065 \\
\hline Once per few weeks & -0.182 & 0.064 & 0.800 \\
\hline Once per week & 0.795 & 1.225 & 0.268 \\
\hline More than once per week & 2.223 & 9.464 & 0.002 \\
\hline \multicolumn{4}{|l|}{ Built Environment } \\
\hline High Social Interaction & 0.177 & 4.384 & 0.036 \\
\hline High Accessibility & 0.078 & 0.816 & 0.366 \\
\hline \multicolumn{4}{|l|}{ ICT and Online Shopping Characteristics } \\
\hline Never shop online [D] & -0.473 & 6.816 & 0.009 \\
\hline High frequency online shoppers [D] & -0.440 & 0.615 & 0.433 \\
\hline Shopping expenditure is less than 100.000 IDR [D] & -1.655 & 73.072 & 0.000 \\
\hline \multicolumn{4}{|l|}{ Socio Demography and Travel Characteristics } \\
\hline Student $[\mathrm{D}]$ & 0.695 & 7.092 & 0.008 \\
\hline $\mathrm{MC}$ user [D] & 0.107 & 0.350 & 0.554 \\
\hline PT user [D] & 0.976 & 10.337 & 0.001 \\
\hline Own private vehicle [D] & -1.501 & 5.206 & 0.023 \\
\hline Multi-Trip [D] & 0.712 & 12.123 & 0.000 \\
\hline \multicolumn{4}{|l|}{ Goodness-of-Fit Parameters } \\
\hline$-2 \mathrm{LL}(0) ;-2 \mathrm{LL}(\beta) ;[\chi 2 ; \mathrm{df} . ; p$-value $]$ & \multicolumn{3}{|c|}{$\begin{array}{c}1513.308 ; 1354.760 \\
{[148.548 ; 10 ; 0.000]}\end{array}$} \\
\hline Cox and Snell $\mathrm{R}^{2}$; Nagelkerke $\mathrm{R}^{2}$; McFadden $\mathrm{R}^{2}$ & \multicolumn{3}{|c|}{$[0.270 ; 0.281 ; 0.098]$} \\
\hline Test of Parallel Lines [ $\chi 2 ; \mathrm{df} . ; p$-value] & \multicolumn{3}{|c|}{$[34.410 ; 30 ; 0.265]$} \\
\hline
\end{tabular}

Link function logit; [D] = dummy variables 1 if yes; 0 otherwise.

Table 8. Estimation result of ordered model for in-store shopping expenditure analysis.

\begin{tabular}{|c|c|c|c|}
\hline Threshold & Estimate & Wald & Sig. \\
\hline$<100.000$ IDR & -3.515 & 12.426 & 0.000 \\
\hline $100.001-250.000$ IDR & -2.371 & 5.714 & 0.017 \\
\hline $250.001-500.000$ IDR & -1.290 & 1.710 & 0.191 \\
\hline $500.001-750.000$ IDR & -0.728 & 0.546 & 0.460 \\
\hline $750.001-1.000 .000 \mathrm{IDR}$ & 0.277 & 0.078 & 0.780 \\
\hline \multicolumn{4}{|l|}{ Built Environment } \\
\hline High Accessibility & 0.147 & 2.999 & 0.083 \\
\hline Green Environment & 0.148 & 2.913 & 0.088 \\
\hline Secure Environment & 0.055 & 0.421 & 0.516 \\
\hline High Social Interaction & -0.058 & 0.471 & 0.493 \\
\hline NMT Friendly & 0.031 & 0.129 & 0.719 \\
\hline \multicolumn{4}{|l|}{ ICT and Online Shopping Characteristics } \\
\hline High frequency online shoppers [D] & -0.771 & 9.686 & 0.002 \\
\hline$>5$ years Internet Experience [D] & -0.249 & 1.269 & 0.260 \\
\hline$>5$ years Smartphone Experience [D] & -0.472 & 4.121 & 0.042 \\
\hline No access to Internet [D] & 0.440 & 5.531 & 0.019 \\
\hline \multicolumn{4}{|l|}{ Socio Demography and Travel Characteristics } \\
\hline Student [D] & 0.449 & 2.976 & 0.084 \\
\hline Senior Citizen [D] & -0.289 & 1.899 & 0.168 \\
\hline$>45$ minutes travel time [D] & -0.983 & 1.751 & 0.186 \\
\hline$>40.000$ IDR transport cost [D] & -1.391 & 5.098 & 0.024 \\
\hline \multicolumn{4}{|l|}{ Goodness-of-Fit Parameters } \\
\hline$-2 \mathrm{LL}(0) ;-2 \mathrm{LL}(\beta) ;[\chi 2 ;$ df.; $p$-value $]$ & \multicolumn{3}{|c|}{$\begin{array}{l}1514.295 ; 1453.653 \\
{[60.641 ; 13 ; 0.000]}\end{array}$} \\
\hline Cox and Snell $\mathrm{R}^{2}$; Nagelkerke $\mathrm{R}^{2}$; McFadden $\mathrm{R}^{2}$ & \multicolumn{3}{|c|}{$[0.118 ; 0.123 ; 0.040]$} \\
\hline Test of Parallel Lines [ $\chi 2 ; \mathrm{df}$;; $p$-value] & \multicolumn{3}{|c|}{$[30.865 ; 52 ; 0.991]$} \\
\hline
\end{tabular}


Shoppers who were students tended to spend higher amounts when shopping, while shoppers with travel costs of more than 40,000 IDR tended to have lower spending. In terms of the built environment characteristics, shoppers who lived in higher accessibility and green areas tended to have a higher shopping expenditure. Interestingly, ICT experience was shown to have significant implications for shopping expenditure. Shoppers with a higher frequency of online shopping tended to spend less on in-store shopping. Shoppers with more than five years of experience in smartphone use also tended to have higher spending. In contrast, shoppers with no access to Internet facilities tended to spend less. It can therefore be said that online shopping is a highly probable substitute for in-store shopping.

\section{Discussion}

This study examines shoppers' behavioural characteristics and investigates the roles of the built environment, socio-demographics, and ICT on in-store shopping trips from shoppers' experiences in developing country in this digital era. In general, this study supports the conclusion from study in developed countries that the selection of shopping location is influenced by accessibility to shops [4] and people conduct multi-purpose and multi-stops [8,9]. Specifically, this study provides new evidence in the case of a developing country in relation to the effect of ICT. Although the adoption of ICT has had a significant effect on in-store shopping activities and travel, which may arguably decrease the effect of physical accessibility on shopping location, our investigation demonstrates the crucial influence of accessibility on the frequency of engaging in-store shopping trips. This study proposes high accessibility as one of the main clusters.

The results also show that spending-related indicators (shopping expenditure and travel costs) significantly influence the choice of transport mode. While prior studies have demonstrated that traditional socio-demographic factors such as income level are indicators of mode choice, the current work adds the factors of shopping expenditure and travel cost as determinants of mode choice for in-store shopping travel. Our analysis also reveals that mode choice is strongly related to the quantity and quality of the items purchased. As stated in the economic concept of utility maximisation [86], individuals tend to seek the best option, based on trading off disutility, to pursue maximum utility. In the context of in-store shopping, shoppers tend to minimise utility in the form of travel cost and comfortableness to accommodate the number of items purchased. Shoppers who spend more on groceries probably acquired more items, resulting in a greater likelihood of using a PC, partly due to the effectiveness of this mode of transport. Meanwhile, the choices of walking and cycling for grocery shopping negatively affect the spending allocation for the shopping trip. The limited carrying capacity of these modes of transportation may prevent people from shopping more. The reason behind this finding is provided by Kim and Park [5] that searching for the best price, random shoppers may prefer high-low stores, want to shop in a larger store, and spend less at a given trip, since they have time to shop around and the larger store provides various buying opportunities. On the other side, high opportunity cost makes the routine shoppers experience difficulty to visit grocery stores less frequently and switch stores, and make them spend more at a given trip, as a way to simplify their shopping problems.

This study underlines the role of the built environment on in-store shopping behaviour. The results show that higher accessibility to PT, main roads, and public and commercial areas from a shopper's residential location leads to higher use of PT. The presence of secure and green residential areas is highly associated with high household incomes, leading to higher preferences for car usage. The role of the built environment is founded on the fact that the location of households is a manifestation of the effects of land and city development. In developing countries such as Indonesia, clustered (closed) forms of residential areas have grown rapidly over recent decades, providing private environments with higher security and comfort for middle-to-upper class residents. These types of residential areas are provided with more green areas and wider spaces in terms of land, resulting in higher prices. These characteristics are associated with a higher tendency to depend on cars for shopping trips. 
This evidence is aligned with the statement by Handy et al. [60] that continuous land price growth has triggered urban sprawl and, creating massive numbers of car users.

This study confirms existing knowledge of the effects of shopping on activity arrangement. Arentze et al. [8] argue that individuals will apply multi-purpose and multi-stop behaviour in order to optimise the use of their resources, for example minimising transport cost. Baker [9] showed that there is a strong relationship between multi-purpose shopping and the mean trip frequency for different states of the space-time model, where the multi-purpose shopping behaviour is not only consumer strategy but multi-purpose shopping as a fundamental bridge in understanding the links between space-time shopping behaviour, income, aggregate household mobility, and the maintenance of a shopping-centre hierarchy. In-store shopping has a strong relationship with activity arrangement, specifically for individual workers who undertake more out-of-home activities, due to the marginal utility provided by in-store shopping [34]. The organisation of these activities materialises in the form of activity chaining, as a way of maximising time usage [39]. This involves adding several stops between the daily trips in the chain to increase the economy of scale of the trip, based on their daily needs and desires. Since in-store shopping requires a physical presence and consequently involves travel, shoppers will maximise their time usage by chaining their shopping activity with other activities. For instance, commuters may make stops in their work-to-home trip for shopping, by finding an available shopping location along their route home. The reason behind is suggested by Bacon [10] that when there are opportunities for 'joint-purpose' trips at fixed and regular intervals, individual will avoid extra travel costs by combining the two activities on the same trip and make an impact on the frequency of the journey to shop. This finding of the study suggests similarity of behaviour between shoppers in developed and developing countries, as stated by Arentze et al. [8], Bacon [10], Baker [9].

These results do not only support those of past studies (e.g., Richards and Ben-Akiva [7], Arentze et al. [8], Bacon [10], Baker [9], Gould and Golob [43], Jou and Mahmassani [38], Gould [37], Gould and Golob [34]), but also offer new insights into the relationship between mode choice and activity chaining to support shopping activity. This study shows that activity arrangements in the form of ST or MT are highly associated with mode choice. The results show that ST journeys (home-shopping-home) are made by shoppers located near shops, a group that has relatively low incomes. Meanwhile, MT activities are typically completed over longer travel distances, probably due to the proximity of the shopping location to the location of the next activity. It is also worth noting that STs are associated with older shoppers (older than 50) who are likely to have lower frequencies for daily activities.

The results of our analysis show that shoppers who use a car for an ST tended to cover lower travel distances than the MT shoppers. This confirms the role of accessibility when individuals consider their options in deciding on a shopping location [4]. The results of the study also show that this group of respondents tends to have higher shopping expenses that those who walk or cycle, confirming that these shoppers optimise their trips by planning their activities in the form of an ST or an MT, affecting the travel distance and selected mode.

We also investigate the effect of ICT experience on travel for shopping activity as a way to test the hypothesis whether individuals are still interested to visit a store for in-store shopping. Prior studies report that the effects of ICT on travel or activities can materialise in both positive and negative ways. The current work demonstrates that ICT experience and access have a significant influence on in-store shopping behaviour. A higher positive experience (i.e., online shopping and smartphone experience) shows evidence of the substitution of online shopping for in-store activities. However, to some extent, we also find that although there is a possibility of substitution for the shopping activities themselves, this is not true for the trip to the store. The experience of physical contact with the goods increases the feeling of trust in the product; the excitement of comparing prices between online and in-store outlets seems to be the main reason for continuing to travel to shops. A trip to visit stores in person will never be eliminated fully, since people still have a positive attitude towards physical visits to stores. When shoppers have sufficient trust or feelings of confidence towards goods, then they tend to 
shop online; this explains the increase in their shopping expenditure. This finding is in line with the statement of Cao et al. [23] that the rise of e-shopping is not likely to be a solution but a challenge to travel reduction, because the Internet as a shopping channel tends to have a complementary effect on in-store shopping. Therefore, it can be concluded that individuals in developing countries still have interest in in-store shopping even if they have a high familiarity with ICT.

\section{Conclusions}

Research on travel from a different background is important to provide a big picture of travel behaviour, including shopping travel behaviour. It is already accepted that there is heterogeneity in shopping travel behaviour. Therefore, a study using different experience is important. This motivation is in line with the suggestion of Sun et al. [12] that there is a need for studying diversification in grocery shopping locations and frequency that can correctly guide consumer demand and provide the basis for the urban planning. This statement shows higher relevancy with the current condition in developing countries where the government, market player, and community struggle to develop a policy to anticipate the market change in the following decade. Developing country experience a wide gap of ICT's influence on transportation as a result of heterogeneity in the community's development. With hundreds of city ranges from the west to the east of Indonesia, it is naturally difficult to have homogenous effects. Similar condition about the heterogeneity of income level, ICT's penetration, or infrastructure readiness are found in other developing countries in the South East Asia region.

This study examines two research questions. Firstly, it examines whether individuals are continuously doing in-store shopping even though ICT is clearly growing and easily reached. Secondly, how grocery shoppers organise their travel to reach shopping locations, using the case of Bandung. This study supports the hypothesis that shoppers simultaneously consider shopping activities, other activities, modes of transport, and shopping expenses. The evidence from Bandung suggests that individuals in developing countries still have a high interest in in-store shopping activities. These findings also support the hypothesis that shoppers in developing countries have similar behaviours in managing shopping activities, arranging travel to accommodate all activities, trading off constraints, needs, and wants, including utilising ICT in their decision-making process.

Higher shopping expenditure implies higher numbers of purchases, which leads to a preference for a mode of transport with higher flexibility and reliability. This case is obvious for the context of motorised transport modes. For the sustainability context, policy makers often need to identify which types of travels and activities that may contribute carbon emission. The study confirms that in-store shopping travels and activities may lead to high frequency of motorised modes, and this type of activity and travel may contribute to the significant proportion of carbon emission from this activity type. A study by Edwards et al. [87] demonstrates that online-based shopping activities are likely to generate less $\mathrm{CO}_{2}$ than those of typical shopping travels. For context of Indonesia, we found that the proportion of in-store shopping travels is still high and most of those trips were carried out with motorised modes. Therefore, this travel pattern evidence may be one of the challenges in developing countries that prevents them decreasing the production of $\mathrm{CO}_{2}$ in the transportation sector.

This study further found that lower trip frequency with walking or cycling were made among the respondents for in-store shopping activity. This study also found that trip-chaining behaviour is used by in-store shoppers as a part of their travel arrangements. It is shown that shoppers using trip-chaining travel longer distances to carry out several activities in different locations. Again, this finding informs the possibility to achieve more sustainable transport system in developing countries by managing travel demand for shopping. The reason is provided by Donaghy et al. [88] that to arrive at settlement patterns, transport systems and patterns of usage that are sustainable, one needs to understand better the constraints upon and drivers of mobility behaviour.

The effect of experience in the use of ICT on in-store shopping activity and travel behaviour is also investigated in this study. Mikalef et al. [89] stated that the amount of purchase and word-of-mouth intentions can be achieved through multiple ways which also depend on gender and spending history. 
The results of this study indicate that higher experience in the use of ICT may imply a more negative effect on the amount of expenditure on in-store shopping. However, there is no evidence that the number of trips to visit in-store shops negatively affects the frequency or time allocated for shopping.

There are several limitations to the results of this study. Firstly, this study only considers grocery shopping activities, without considering respondents' full daily activities. Therefore, a future study should be conducted to understand grocery shopping activities as part of the respondent's full daily activities. Secondly, a follow-up study should investigate the consistency of grocery shopping activity from day-to-day during a week. These extended studies may provide knowledge allowing researchers to anticipate how transportation systems should be managed in the digital age, in a populous city, and in developing countries where changes are arising rapidly. Thirdly, a study to find suitable measures of travel demand management $[19,20]$ in the context of developing countries to support shopping activities that allow transport to be more sustainable.

Author Contributions: Conceptualization, T.B.J.; methodology, T.B.J., A.K.M.T., and M.R.; software, M.R.; validation, T.B.J. and A.K.M.T.; data curation, A.K.M.T.; writing-original draft preparation, T.B.J., A.K.M.T., M.R.; writing—review and editing, T.B.J., A.K.M.T.; project administration, T.B.J.; funding acquisition, T.B.J.

Funding: This research was funded by the Directorate of Research and Community Services, Directorate General of Research and Development Strengthening, Ministry of Research, Technology and Higher Education, Republic of Indonesia, grant number 1598/K4/KM/2017.

Acknowledgments: The authors would like to thank all parties who participated in data collection and Rifza Fakhrial Elmiawan for initiating the analysis.

Conflicts of Interest: The authors declare no conflict of interest.

\section{References}

1. Salomon, I.; Koppelman, F. A framework for studying teleshopping versus store shopping. Transp. Res. Part A 1988, 22, 247-255. [CrossRef]

2. Schmid, B.; Axhausen, K.W. In-store vs. online shopping of search and experience goods: A hybrid choice approach. In Proceedings of the 5th International Choice Modeling Conference (ICMC 2017), Cape Town, South Africa, 3-5 April 2017; IVT ETH: Zurich, Switzerland, 2017.

3. Simma, A.; Schilch, R.; Axhausen, K.W. Destination Choice Modelling for Different Leisure Activities; Working Paper: 99; IVT ETH: Zurich, Switzerland, 2002.

4. Recker, W.W.; Kostyniuk, L.P. Factors influencing destination choice for the urban groceries trip. Transportation 1978, 7, 19-33. [CrossRef]

5. Kim, B.-D.; Park, K. Studying Patterns of Consumer's Grocery Shopping Trip. J. Retail. 1997, 73, 501-517. [CrossRef]

6. Bhat, C.R. Analysis of travel mode and departure time choice for urban shopping trips. Transp. Res. Part B Methodol. 1998, 32, 361-371. [CrossRef]

7. Richards, M.G.; Ben-Akiva, M. A simultaneous destination and mode Choice model for shopping trips. Transportation 1974, 3, 343-356. [CrossRef]

8. Arentze, T.; Borgers, A.; Timmerman, H. A model of multi-purpose shopping trip behavior. Reg. Sci. 1993, 72, 239-256. [CrossRef]

9. Baker, R.G.V. Multipurpose shopping behaviour at planned suburban shopping centres: A space-time analysis. Environ. Plan. A 1996, 28, 611-630. [CrossRef]

10. Bacon, R.W. Combined trips and the frequency of shopping. J. Retail. Consum. Serv. 1995, 2, 175-183. [CrossRef]

11. Bhat, C.R.; Frusti, T.; Zhao, H.; Schönfelder, S.; Axhausen, K.W. Intershopping duration: An analysis using multiweek data. Transp. Res. Part B 2004, 38, 39-60. [CrossRef]

12. Sun, Y.; Tarigan, A.K.M.; Waygood, E.O.D.; Wang, D. Diversity in diversification: An analysis of shopping trips in six-week travel diary data. J. Zhejiang Univ. SCIENCE A 2017, 18, 234-244. [CrossRef]

13. Mokhtarian, P.L. A conceptual analysis of the transportation impacts of B2C e-commerce. Transportation 2004, 31, 257-284. [CrossRef] 
14. Hsiao, M.H. Shopping mode choice: Physical store shopping versus e-shopping. Transp. Res. Part E 2009, 45, 86-95. [CrossRef]

15. Mokhtarian, P.L.; Salomon, I. How derived is the demand for travel? Some conceptual and measurement considerations. Transp. Res. Part A Policy Pract. 2001, 35, 695-719. [CrossRef]

16. Suel, E.; Polak, J.W. Development of joint models for channel, store, and travel mode choice: Grocery shopping in London. Transp. Res. Part A 2017, 99, 147-162. [CrossRef]

17. Santos, A.; McCuckin, N.; Nakamoto, H.Y.; Gray, D.; Liss, S. Summary of Travel Trends. 2009 National Household Travel Survey; Federal Highway Administration: Washington, DC, USA, 2011.

18. Lee, R.J.; Sener, I.N.; Mokhtarian, P.L.; Handy, S.L. Relationships between the online and in-store shopping frequency of Davis, California residents. Transp. Res. Part A Policy Pract. 2017, 100, 40-52. [CrossRef]

19. Gärling, T.; Eek, D.; Loukopoulos, P.; Fujii, S.; Johansson-Stenman, O.; Kitamura, R.; Pendyala, R.; Vilhelmson, B. A conceptual analysis of the impact of travel demand management on private car use. Transp. Policy 2002, 9, 59-70. [CrossRef]

20. Gärling, T.; Schuitema, G. Travel demand management targeting reduced private car use: Effectiveness, public acceptability and political feasibility. J. Soc. Issues 2007, 63, 139-153. [CrossRef]

21. May, A.D. Urban Transport and Sustainability: The Key Challenges. Int. J. Sustain. Transp. 2013, 7, $170-185$. [CrossRef]

22. Rotem-Mindali, O.; Weltevreden, J.W. Transport effects of e-commerce: What can be learned after years of research? Transportation 2013, 40, 867-885. [CrossRef]

23. Cao, X.J.; Xu, Z.; Douma, F. The interactions between e-shopping and traditional in-store shopping: An application of structural equations model. Transportation 2012, 39, 957-974. [CrossRef]

24. Rotem-Mindali, O.; Salomon, I. The impacts of E-retail on the choice of shopping trips and delivery: Some preliminary findings. Transp. Res. Part A Policy Pract. 2007, 41, 176-189. [CrossRef]

25. Mikalef, P.; Giannakos, M.N.; Pateli, A.G. Exploring the Business Potential of Social Media: An Utilitarian and Hedonic Motivation Approach. In Proceedings of the 25th Bled eConference eDependability: Reliable and Trustworthy eStructures, eProcesses, eOperations and eServices for the Future, Bled, Slovenia, 17-20 June 2012.

26. Mikalef, P.; Giannakos, M.; Pateli, A. Shopping and word-of-mouth intentions on social media. J. Theor. Appl. Electron. Commer. Res. 2013, 8, 17-34. [CrossRef]

27. Zhang, K.Z.; Benyoucef, M. Consumer behaviour in social commerce: A literature review. Decis. Support Syst. 2016, 86, 95-108. [CrossRef]

28. Visser, E.j.; Lanzendorf, M. Mobility and accessibility effects of B2C ecommerce: A literature review. Tijdschrift voor Economische en Sociale Geografie 2004, 95, 189-205. [CrossRef]

29. Girard, T.; Korgaonkar, P.; Silverblatt, R. Relationship of type of product, shopping orientations, and demographics with preference for shopping on the Internet. J. Bus. Psychol. 2003, 18, 101-120. [CrossRef]

30. Park, C.W.; Iyer, E.S.; Smith, D.C. The effects of situational factors on in-store grocery shopping behaviour: The role of store environment and time available for shopping. J. Consum. Res. 1989, 15, 422-433. [CrossRef]

31. Tauber, E.M. Why do people shop? J. Mark. 1972, 36, 46-49. [CrossRef]

32. Farag, S. E-Shopping and Its Interactions with In-Store Shopping. Ph.D. Thesis, Faculty of Geosciences, Utrecht University, Utrecht, The Netherlands, 2006.

33. Farag, S.; Schwanen, T.; Dijst, M.; Faber, J. Shopping online and/or in-store? A structural equation model of the relationships between e-shopping and in-store shopping. Transp. Res. Part A Policy Pract. 2007, 41, 125-141. [CrossRef]

34. Gould, J.; Golob, T.F. Will electronic home shopping reduce travel? Access (Mag. Univ. Calif. Transp. Center) 1998, 12, 26-31.

35. Peterson, R.A.; Balasubramanian, S.; Bronnenberg, B.J. Exploring the implications of the internet for consumer marketing. J. Acad. Mark. Sci. 1997, 25, 329-346. [CrossRef]

36. Steinfield, C.W.; Whitten, P. Community level socio-economic impacts of electronic commerce. J. Comput. -Mediat. Commun. 1999, 5. [CrossRef]

37. Gould, J. Driven to shop? Role of transportation in future home shopping. Transp. Res. Rec. 1998, 1617, 149-156. [CrossRef]

38. Jou, R.-C.; Mahmassani, H.S. Comparative analysis of day-to-day trip-chaining behaviour of urban commuters in two cities. Transp. Res. Rec. 1997, 1607, 163-170. [CrossRef] 
39. Hägerstrand, T. What about people in regional science? Pap. Reg. Sci. 1970, 24, 7-21. [CrossRef]

40. Yamamoto, T.; Kitamura, R. An analysis of time allocation to in-home and out-of-home discretionary activities across working days and non-working days. Transportation 1999, 26, 231-250. [CrossRef]

41. Susilo, Y.O. The Short Term Variability and the Long Term Changes of Individual Spatial Behaviour in Urban Areas. Ph.D. Thesis, Department of Urban Management Graduate School of Engineering, Kyoto University, Kyoto, Japan, 2005.

42. Brunow, S.; Gründer, M. The impact of activity chaining on the duration of daily activities. Transportation 2013, 40, 981-1001. [CrossRef]

43. Gould, J.; Golob, T.F. Shopping without Travel or Travel without Shopping? An Investigation of Electronic Home Shopping. Transp. Rev. 1997, 17, 355-376. [CrossRef]

44. Levinson, D.; Kumar, A. Activity, travel, and the allocation of time. J. Am. Plan. Assoc. 1995, 61, 458-470. [CrossRef]

45. Kitamura, R.; Mokhtarian, P.L.; Laidet, L. A micro-analysis of land use and travel in five neighborhoods in the San Francisco Bay Area. Transportation 1997, 24, 125-158. [CrossRef]

46. Axhausen, K.W.; Zimmermann, A.; Schönfelder, S.; Rindsfüser, G.; Haupt, T. Observing the rhythms of daily life: A six-week travel diary. Transportation 2002, 29, 95-124. [CrossRef]

47. Kurani, K.S.; Lee-Gooselin, M.E.H. Synthesis of past activity analysis applications. In Proceedings of the Activity-Based Travel Forecasting Conference, New Orleans, LA, USA, 2-5 June 1996; pp. 51-77.

48. McGuckin, N.; Murakami, E. Examining trip-chaining behaviour: Comparison of travel by men and women. Transp. Res. Rec. J. Transp. Res. Board 1999, 1693, 79-85. [CrossRef]

49. Primerano, F.; Taylor, M.A.P.; Pitaksringkarn, L.; Tisato, P. Defining and understanding trip chaining behaviour. Transportation 2008, 35, 55-72. [CrossRef]

50. Subbarao, S.S.V.; Krishna Rao, K.V. Trip chaining behavior in developing countries: A study of Mumbai Metropolitan Region, India. Eur. Transp. (Trasporti Europei) 2013, 53, 1-30.

51. Bowman, J.; Ben-Akiva, M. Activity Based Travel Demand Model System with Daily Activity Schedules. Master's Thesis, Massachusetts Institute of Technology, Cambridge, MA, USA, 1995.

52. Bhat, C.R.; Singh, S.K. A comprehensive daily activity-travel generation model system for workers. Transp. Res. Part A 2000, 34, 1-22. [CrossRef]

53. Kitamura, R.; van der Hoorn, T. Regularity and irreversibility of weekly travel behaviour. Transportation 1987, 14, 227-251. [CrossRef]

54. Kasturirangan, K.; Pendyala, R.; Koppelman, F. History dependency in daily activity participation and time allocation for commuters. Transp. Res. Rec. J. Transp. Res. Board 2002, 1807, 129-136. [CrossRef]

55. Ewing, R.; Cervero, R. Travel and the built environment: A synthesis. Transp. Res. Rec. J. Transp. Res. Board 2001, 1780, 87-114. [CrossRef]

56. McNally, M.G.; Ryan, S. A Comparative Assessment of Travel Characteristics for Neo-Traditional Developments; Working Paper, University of California Transportation Center (UTCT) No 142; University of California: Berkeley, CA, USA, 1992.

57. Kitamura, R.; Fujii, S.; Pas, E. Time-use data, analysis and modeling: Toward the next generation of transportation planning methodologies. Transp. Policy 1997, 4, 225-235. [CrossRef]

58. Reilly, M.; Landis, J. The Influence of Built-Form and Land Use on Mode Choice; University of California Transportation Center Research Paper, Work Conducted at the Institute of Urban and Regional Development, IURD WP 2002-4; University of California: Berkeley, CA, USA, 2003.

59. Schwanen, T.; Mokhtarian, P.L. What affects commute mode choice: Neighborhood physical structure or preferences toward neighborhoods? J. Transp. Geogr. 2005, 13, 83-99. [CrossRef]

60. Handy, S.; Cao, X.; Mokhtarian, P. Correlation or causality between the built environment and travel behaviour? Evidence from Northern California. Transp. Res. Part D Transp. Environ. 2005, 10, 427-444. [CrossRef]

61. Cao, X.; Handy, S.L.; Mokhtarian, P.L. The influences of the built environment and residential self-selection on pedestrian behavior: Evidence from Austin, TX. Transportation 2006, 33, 1-20. [CrossRef]

62. Handy, S. Critical Assessment of the Literature on the Relationships among Transportation, Land Use, and Physical Activity; UCD-ITS-RP-05-67, Transportation Research Board Special Report; The National Academies of Sciences, Engineering, and Medicine: Washington, DC, USA, 2005. 
63. Mokhtarian, P.L.; Tal, G. Impacts of ICT on travel behavior: A tapestry of relationships. In The SAGE Handbook of Transport Studies; Rodrigue, J.-P., Notteboom, T., Shaw, J., Eds.; SAGE Publications Ltd.: Los Angeles, CA, USA, 2013.

64. Cao, X. E-Shopping, spatial attributes, and personal travel: A review of empirical studies. Transp. Res. Rec. J. Transp. Res. Board 2009, 2135, 160-169. [CrossRef]

65. Hubers, C.; Schwanen, T.; Dijst, M. ICT and temporal fragmentation of activities: An analytical framework and initial empirical findings. Jtijdschrift voor Economische en Sociale Geografie 2008, 99, 528-546. [CrossRef]

66. Farag, S.; Schwanen, T.; Dijst, M. Empirical Investigation of Online Searching and Buying and Their Relationship to Shopping Trips. Transp. Res. Rec. J. Transp. Res. Board 2005, 1926, 242-251. [CrossRef]

67. Farag, S.; Krizek, K.J.; Dijst, M. E-Shopping and Its Relationship with In-Store Shopping: Empirical Evidence from the Netherlands and the USA. Transp. Rev. 2006, 26, 43-61. [CrossRef]

68. Zmud, J.; Bricka, S.G.; Casas, J. Impact of Shopping via Internet on Travel for Shopping Purposes. In Proceedings of the 80th Annual Meeting of the Transportation Research Board, Washington, DC, USA, 7-11 January 2001.

69. Ferrell, C.E. Home-Based Teleshoppers and Shopping Travel: Do Teleshoppers Travel Less? Transp. Res. Rec. J. Transp. Res. Board 2004, 1894, 241-248. [CrossRef]

70. Ferrell, C.E. Home-Based Teleshopping and Shopping Travel: Where Do People Find the Time? Transp. Res. Rec. J. Transp. Res. Board 2005, 1926, 212-223. [CrossRef]

71. Lila, P.C.; Anjaneyulu, M.V.L.R. Modeling the Impact of ICT on the Activity and Travel Behaviour of Urban Dwellers in Indian Context. Transp. Res. Procedia 2016, 17, 418-427. [CrossRef]

72. Yamane, T. Statistics: An Introductory Analysis, 2nd ed.; Harper and Row: New York, NY, USA, 1967.

73. Israel, G.D. Determining Sample Size; PEOD6; Agricultural Education and Communication Department, Florida Cooperative Extension Service, Institute of Food and Agricultural Sciences, University of Florida: Gainesville, FL, USA, 2012.

74. BPS (Statistics of Bandung City). Bandung City in Figures; BPS - Statistics Indonesia: Bandung, Indonesia, 2015.

75. BPS (Statistics of Bandung City). Total Population by Age Group and Sex in Bandung Municipality. 2016. Available online: https:/ / bandungkota.bps.go.id/statictable/2017/08/29/104/jumlah-penduduk-menurutkelompok-umur-dan-jenis-kelamin-di-kota-bandung-2016-.html (accessed on 24 January 2019).

76. BPS (Statistics of Bandung City). Hasil Survei Biaya Hidup 2012. Available online: https:/ /jabar.bps.go. id/pressrelease/2012/12/03/452/hasil-survei-biaya-hidup-2012-di-jawa-barat--rata-rata-biaya-hidup-nilai-konsumsi-rumah-tangga-gabungan-7-kota--per-bulan-di-jawa-barat-sebesar-rp--5--431--863.html (accessed on 24 January 2019).

77. Strathman, J.G.; Dueker, K.J. Understanding trip chaining. In 1990 NPTS Special Reports on Trip and Vehicle Attributes; Publication FHWA-PL-95-033; FHWA; US Department of Transportation: Washington, DC, USA, 1995.

78. Bawa, K.; Ghosh, A. A model of household grocery shopping behaviour. Mark. Lett. 1999, 10, 149-160. [CrossRef]

79. Hair, J.F.; Black, W.C.; Babin, B.J.; Anderson, R.E.; Tatham, R.L. Multivariate Data Analysis, 6th ed.; Prentice Hall: New York, NY, USA, 2006.

80. Kaiser, H.F. An index of factorial simplicity. Psychometrika 1974, 39, 31-36. [CrossRef]

81. Hutcheson, G.D.; Sofroniou, N. The multivariate Social Scientist: Introductory Statistics Using Generalized Linear Models; Sage: Thousand Oaks, CA, USA, 1999.

82. Burns, R. Cluster Analysis. In Business Research Methods and Statistics Using SPSS; Sage Publications: London, UK, 2008.

83. Satish, S.M.; Bharadhwaj, S. Information search behaviour among new car buyers: A two-step cluster analysis. IIMB Manag. Rev. 2010, 22, 5-15. [CrossRef]

84. Mokhtarian, P.L. Telecommuting and travel: State of the practice, state of the art. Transportation 1991, 18, 319-342. [CrossRef]

85. Mokhtarian, P.L. If telecommunication is such a good substitute for travel, why does congestion continue to get worse? Transp. Lett. 2009, 1, 1-17. [CrossRef]

86. Koppelman, F.S.; Bhat, C. A self instructing course in mode choice modeling: Multinomial and nested Logit Models; U.S. Department of Transportation: Federal Transit Administration: Washington, DC, USA, 2006. 
87. Edwards, J.B.; McKinnon, A.C.; Cullinane, S.L. Comparative analysis of the carbon footprints of conventional and online retailing: A "last mile" perspective. Int. J. Phys. Distrib. Logist. Manag. 2010, 40, 103-123. [CrossRef]

88. Donaghy, K.; Rudinger, G.; Stefan, P. Societal trends, mobility behaviour and sustainable transport in Europe and North America. Transp. Rev. 2004, 24, 679-690. [CrossRef]

89. Mikalef, P.; Pappas, I.O.; Giannakos, M. Consumer intentions on social media: A fsQCA analysis of motivations. In Proceedings of the Conference on e-Business, e-Services and e-Society, Swansea, UK, 13-15 September 2016; Springer: Cham, Switzerland, 2016; pp. 371-386. [CrossRef]

2019 by the authors. Licensee MDPI, Basel, Switzerland. This article is an open access article distributed under the terms and conditions of the Creative Commons Attribution (CC BY) license (http:/ / creativecommons.org/licenses/by/4.0/). 